\title{
RAZVEZANE METAFORE? INOVATIVNE IN LEKSIKALIZIRANE METAFORE V SLOVENŠČINI
}

\section{Kaja DOLAR}

Ljubljana, Slovenija

Dolar, K. (2015): Razvezane metafore? Inovativne in leksikalizirane metafore $v$ slovenščini. Slovenščina 2.o, 3 (1): 90-121.

URL: http://www.trojina.org/slovenscina2.o/arhiv/2015/2/Slo2.o_2015_1_o5.pdf.

Metafora je teoretski problem, ki že dolgo presega meje lingvistike in je tako predmet različnih filozofskih, psiholoških, antropoloških idr. razprav. V lingvistiki je bila metafora dolgo predmet raziskav v retoriki, posebno mesto je dobila v strukturalni lingvistiki, prisotna pa je tudi v različnih pragmatičnih, kognitivnih in besedilnih analizah. $\mathrm{V}$ prispevku je $\mathrm{v}$ ospredju analiza metafore $\mathrm{z}$ lingvističnega vidika, in sicer glede na njeno slovnično oziroma sintaktično strukturo (enobesedne metafore/metaforične besedne zveze, in praesentia/in absentia itn.), pomensko polje (in s tem povezan semantični transfer) ter stopnjo konvencionalnosti (na lestvici med inovativnimi in leksikaliziranimi metaforami). Primere smo zbrali v nekonvencionalnem korpusu: v spletni bazi Razvezani jezik. Gre za slovenski kolaborativni slovar, kjer lahko govorci prosto prispevajo nove besede (formalne neologizme) ali nove pomene že obstoječih besed (semantične neologizme) in je $\mathrm{z}$ vidika inovativnosti zato še posebej zanimiv. Rezultati raziskave kažejo, da so v korpusu najpogostejše živalske metafore, prav tako najdemo relativno veliko število reifikacijskih metafor, ki slonijo na metaforični zamenjavi živega bitja z neživim predmetom. Prisotne so tudi fitomorfne oziroma rastlinske metafore, antropomorfne pa so redke. V omenjenih kategorijah najdemo metaforične izraze za karakterne oznake oziroma vedenje ljudi, za dele človeškega telesa, človeška dejanja in splošnejše oznake. Razvezani jezik poleg velikega števila konvencionalnih, leksikaliziranih metafor vsebuje tudi inovativne, t. i. žive metafore, ki vzpostavljajo nove pomene, in zdi se, da je prav beleženje teh rab še posebej pomembno za nadaljnje raziskovanje.

Ključne besede: kreativne metafore, leksikalizirane metafore, jezikovna inovativnost, kolaborativni slovar, zgodovina metafore 


\section{UVOD: KAKO MISLITI METAFORO?}

Metafora je univerzalen fenomen, ki obstaja v domala vseh jezikih in kulturah. Gre za izredno kompleksen problem, ki ga je možno obravnavati z več zornih kotov in v različnih teoretskih okvirih. Tako je metafora predmet antropoloških, filozofskih, psiholoških, politoloških, psihoanalitičnih, pedagoških in drugih raziskav, posebno mesto pa zavzema v literarnih študijah in literaturi, kjer ima ključno vlogo v poetični funkciji jezika. Mnoge raziskave (Lala 2005 idr.) poudarjajo pomembnost interdisciplinarnega pristopa k problemu metafore in zdi se, da je metaforo potrebno obravnavati v širših humanističnih okvirih.

V naši raziskavi se osredotočamo na lingvistično analizo metafore. Najprej bomo podrobno predstavili različna teoretska izhodišča in miselne okvire, v katerih lahko »mislimo« metaforo. Nato se bomo osredotočili na jezikovne vidike metafore, kjer bomo analizirali slovnične in sintaktične strukture metafor in metaforičnih besednih zvez ter preučili razliko med inovativnimi in leksikaliziranimi metaforami, torej metaforami, ki vzpostavljajo neko novo analogijo ter terjajo lastno interpretacijo, ter metaforami, ki so prešle v splošno rabo in jih govorci interpretirajo kot semantični blok. Podrobneje bomo analizirali metafore $\mathrm{v}$ povsem nekonvencionalnem korpusu, kolaborativnem slovarju Razvezani jezik, ki je prosto dostopni spletni slovar slovenskega jezika, kjer lahko govorci prispevajo nove besede ali nove pomene že obstoječih besed. Zdi se, da prav to omogoča nastanek velikega števila inovativnih metafor, ki jih bomo preučili z več zornih kotov (semantičnega, slovničnega itn.). Čeprav Razvezani jezik ni reprezentativen korpus, pa nam lahko veliko pove o aktualnih težnjah jezikovnega razvoja v slovenskem jeziku. 


\section{METAFORA V RAZLIČNIH TEORETSKIH OKVIRIH}

Metafora se je kot jezikovni in miselni problem pojavila že zelo zgodaj, še danes pa je predmet številnih znanstvenih razprav. Obstaja veliko število različnih definicij metafore, prav njihova številčnost pa priča o kompleksnosti problema. Zgodovino teorij metafore je zaznamovalo več zanimivih preobratov.

Sama beseda 'metafora' je grškega izvora: metá pomeni 'vmes, preko', phérō pa 'nesem' (Slovenski etimološki slovar 1997: 337). Prvi, ki je obširneje obravnaval metaforo, je bil Aristotel, ki je kot bistveni značilnosti metafore izpostavi prenos pomena in analogijo kot osnovo za ta prenos (Aristoteles 1982: 96-97). V sklopu antične retorike so se metafori podrobneje posvečali tudi Ciceron, Kvintilijan in Seneka, ponovno pa je obravnava metafore stopila v prvi plan v francoski retoriki 16. stoletja in je povezana z imeni, kot so Foquelin (16. st.), Beauzée, Marmontel (17. st.), Dumarsais (18. st.), Fontanier (19. st.) idr. Eno najbolj znanih definicij metafore je leta 1730 prispeval prav Dumarsais, ki jo je definiral kot figuro, ki transponira lastni pomen kake besede na kako drugo, ki ji pritiče zgolj zaradi primerjave $\mathrm{v}$ duhu; tako beseda, uporabljena v metafori, dobi namesto lastnega pomena drug pomen; le zaradi nove zveze terminov dobijo besede metaforični pomen (Dumarsais 1977: 112-127).

Ricœur ugotavlja, da je metafora v retoriki predvsem trop oziroma figura, ki je osnovana na podobnosti, in zadeva poimenovanje oziroma preimenovanje, in sicer na osnovi deviacije od prvotnega pomena. Prav podobnost omogoča zamenjavo prvotne besede z metaforično. Metafora ni del semantične inovacije, ampak je le retorični ornament (Ricœur v Foessel in Lamouche 2007: 114). Tako jo še danes najdemo v različnih retoričnih klasifikacijah in stilističnih tipologijah: najpogosteje velja za figuro, ki je osnovana na analogiji oziroma podobnosti (Ricœur 1975), spet drugje je umeščena med figure, ki temeljijo na implicitni primerjavi (Bacry 1992) ali na združitvi oziroma asociaciji različnih pojmov (Beth in Marpeau 2005: 33). Šele sodobna semantika obravnava metaforo na ravni stavka oziroma metaforične izjave, kjer je bistvena napetost 
med različnimi pojmi. Namesto zamenjave (substitucije) imamo pojem pomenskega zdrsa, ki se zgodi, ko je dobesedni pomen absurden oziroma ne pertinenten in stopi na njegovo mesto alternativni, metaforični pomen (Ricœur v Foessel in Lamouche 2007: 115-119).

Za razliko od metafore je v primeri oziroma komparaciji analogija eksplicirana. Prav tako se metafora razlikuje od alegorije, ki strukturira razumevanje celotnega besedila, in od katahreze, ki je sama po sebi metaforično poimenovanje, kadar dobesedno ne obstaja in je kot taka nujen del besedišča (kot denimo noga mize). Na Fontanierovo teorijo (Fontanier 1977) in pojem katahreze se v svoji polemiki naveže tudi Derrida s svojim dekonstrukcijskim branjem v sloviti polemiki z Ricœurjem: za Derridaja ne moremo misliti zunaj metaforičnega, zato tudi ni možna delitev na prvotni in metaforični pomen, pri čemer metafora za Derridaja izhaja iz teksta oziroma tekstualnosti, nasprotno pa je za Ricœurja del samega diskurza (Amalric 2006: 52-54, 58; Derrida 1972: 305-306).

Pojmovanje metafore kot retorične figure se je bistveno spremenilo šele $\mathrm{v}$ sodobni lingvistiki. Roman Jakobson ji pripiše posebno mesto $\mathrm{v}$ jeziku: metafora in metonimija sta osnovna jezikovna principa, ki določata, strukturirata in organizirata celotno govorico. Greimas je apliciral strukturalno metodo na semantiko, pri čemer je analiziral prisotnost oziroma odsotnost semov, najmanjših pomenskih enot v strukturalni semantiki (za besedi maček in mačka je denimo distinktivna poteza oziroma sem spol) (Greimas 1966). Pri analizi metafore gre torej za analizo semov posameznih pojmov, saj metafora pomeni zamenjavo sema na paradigmatski ravni (ibid.). Za razliko od Jakobsona, ki metaforo razume kot osnovni vidik jezika, je Greimas zvedel metaforo zgolj na nivo pomenskosestavinske analize. Ponovno je strukturalno semantiko oživil Rastier, ki je metaforo z analizo izotopij prenesel na raven besedilne analize (Rastier 1987).

Drug velik in izredno zanimiv preobrat se je $\mathrm{v}$ teoriji metafore zgodil na 
področju jezikovne pragmatike. Ta je postavila v ospredje pomen situacije izjavljanja, konteksta in intencionalnosti. Za metaforo - kot tudi na splošno za vse implicitne jezikovne vsebine - je bistvena razlika med besednim pomenom na eni strani in pomenom izjave na drugi strani (Searle 2002). Searle tako zavrača tradicionalno delitev na dobesedni in metaforični pomen, saj se pomen konstruira v procesu izjavljanja in je neposredno odvisen od konteksta. Prav tako ugotavlja - in prav tu se zdi, da je naredil največji preboj - , da je podobnost del sklepanja in zato ključna $v$ interpretaciji metafore, ni pa nujno sestavni del pomena. Opozarja na dejstvo, da lahko metafora učinkuje tudi, če je podobnost neresnična. To velja za primer »Richard is a gorilla « (Searle 2002), saj gre za naša prepričanja o gorilah (da so nasilne ipd.), ne pa za realna dejstva (gorile so v resnici boječe) in da podobnost v splošnem ni del oziroma ne deluje kot resničnostni pogoj, temveč predvsem kot strategija za interpretacijo, ki pa zahteva aktivno razumevanje (Searle 2002).

Z implicitnimi vsebinami sta se podrobneje ukvarjala tudi Grice in Ducrot. Grice vzpostavi princip sodelovanja kot temeljni pogoj vsake komunikacije ter povzame konverzacijska načela v t. i. konverzacijskih maksimah o resničnosti, relevatnosti, informativnosti in jasnosti (Grice 1989). Metaforo tako razlaga kot kršitev maksime o resničnosti, saj je govorčeva izjava v dobesednem pomenu neresnična in je $\mathrm{v}$ procesu sklepanja potrebno poiskati drugi, alternativni pomen (ibid.). $V$ francoskem miselnem prostoru je Ducrot metaforo obravnaval predvsem v sklopu t. i. predpostavk in podmen (Ducrot 1984). Metafora je nekakšna mešanica, saj zanjo veljajo nekatere lastnosti enega in drugega.

Nadaljnje podrobne pragmatične analize sta prispevala Wilson in Sperber, obenem pa sta se s pojmom relevantnosti, ki ga je potrebno razumeti kot težnjo k maksimalni učinkovitosti, že močno približala kognitivnim znanostim. Nedobesedne izjave, ki predstavljajo večji del komunikacije in kamor med drugim sodi tudi metafora, niso le relevantne same na sebi, ampak tudi produktivne in bogatejše kot dobesedne izjave, saj lahko ustvarijo več kontekstualnih učinkov z manj kognitivnega napora. Sperber in Wilson (1989: 
336-356) metaforo, podobno kot metonimijo, sinekdoho in hiperbolo, uvrščata med načine za optimizacijo procesov sklepanja.

Zdi se, da je danes teorija metafore razdeljena na dva tabora. Na eni strani imamo kognitivne pristope, kamor se uvrščajo Turner, Fauconnier (t. i. konceptualna integracija, Fauconnier in Turner 1998), Kleiber (t. i. semantika prototipa, Kleiber 1990, 1999), Langacker idr., ki izhajajo predvsem iz kognitivnega zastavka Lakoffa in Johnsona $\mathrm{v}$ osemdesetih letih (t. i. konceptualna teorija metafore, Lakoff in Johnson 1992, Lakoff 2002).

Tej smeri se sopostavlja alternativa: besediloslovje oziroma besedilna analiza. V francoskem prostoru je v ospredju interpretativna semantika, ki se opira na teoretski okvir Rastiera (1987), ki po zgledu strukturalne lingvistike analizira seme, osnovne pomenske enote oziroma sestavine pomena, odnose med njimi in njihove kombinacije, ter izotopije, večkratno pojavljanje istega sema. Toda Rastier za razliko od Greimasa analize ne omeji na leksikalno raven, temveč jo aplicira na višjih jezikovnih ravneh. Po Rastieru so izotopije različno dolge: lahko zajemajo le besedno zvezo ali pa celotni tekst. Metaforične povezave tako nastanejo na diskurzivnem nivoju, na podlagi izotopij v sicer nezdružljivih kombinacijah semov. Za interpretativno semantiko pomen tako ni dan vnaprej, ampak je odvisen od konteksta, konstituira pa se šele na diskurzivni ravni, četudi se osnovna enota (sem) nahaja hierarhično nižje.

Čeprav sta si teoretska okvira kognitivne in diskurzivne lingvistike po svoji osnovni usmeritvi, implikacijah in analizi povsem različna, pa jima je skupno, da je pomen vselej odvisen od konteksta in da je ta za metaforo ključnega pomena. Da lahko metaforo ustrezno interpretiramo, nujno potrebujemo kontekst, ki pa lahko vsebuje jezikovne ali nejezikovne elemente. Naše osnovno izhodišče je, da kontekst obenem ustvarja in pogojuje metaforični pomen. Metaforo smo za potrebe naše raziskave definirali kot zamenjavo na paradigmatski osi, ki sloni na implicitni primerjavi, kot operacijo, kjer pride do zbližanja oziroma trka različnih semantičnih polj (Bacry 1992: 59-81), pri 
čemer bomo analizirali izhodiščni in diskurzivni pomen metaforičnih izrazov.

V slovenskem prostoru je preučevanje metafore največkrat predmet literarnozgodovinskih razprav. Tako se študije osredotočajo na metaforiko pri določenem avtorju ali v določenem obdobju (prim. Pogorelec 1986, Čeh Steger 2001, Novak Popov 1997). V širšem teoretskem kontekstu so se z metaforo ukvarjali Kante (1996 in 1998), Močnik (1988) idr. V jezikoslovju se študije metafore pojavljajo v okviru leksikologije in slovaropisja (Snoj 2010; VidovičMuha 2000), frazeologije (Kržišnik 1994), terminologije (Stramljič Breznik 2004) ipd., prav tako pa študije postavljajo ospredje metaforo v političnih idr. diskurzih (Bratož 2010).

\section{NEKONVENCIONALNI KORPUS}

$\mathrm{V}$ raziskavi smo podrobno preučili metafore $\mathrm{v}$ nekonvencionalnem korpusu slovenskega jezika, v kolaborativnem slovarju Razvezani jezik, Prosti slovar žive slovenščine, ki je odprti spletni slovar slovenskega jezika, in tudi del slovenskega nacionalnega korpusa Nova beseda. Gre za povsem edinstven in lingvistično zelo zanimiv korpus, zato mu bomo namenili nekaj besed.

\subsection{Korpus Razvezani jezik}

Razvezani jezik, Prosti slovar žive slovenščine je nastal leta 2004. To je spletni kolaborativni slovar, kar pomeni, da ni namenjen zgolj prebiranju, ampak tudi aktivnemu sodelovanju, ki poteka na podoben način kot pri spletni enciklopediji Wikipedija. Prvi tovrstni kolaborativni slovar je bil Urban Dictionary, ki je nastal leta 1999, danes pa najdemo na spletu kolaborativne slovarje za številne jezike. V njih pisci lahko tako prispevajo nova gesla, nove članke, prav tako pa lahko spreminjajo in dopolnjujejo že obstoječe članke, pri čemer ni nobenih posebnih navodil ali posegov (z izjemo prepovedi sovražnega govora, ki pa se po besedah urednice Alenke Pirman pojavlja razmeroma redko). Sprva je bil Razvezani jezik zasnovan kot frazeološki slovar slovenskega 
jezika, ki so ga pisci polnili z nadvse raznovrstnimi vsebinami in tako je nastal kolaborativni slovar žive slovenščine. Danes vsebuje leksikalna baza preko 4700 gesel in slovarskih člankov, ${ }^{1}$ kar je po velikosti povsem primerljivo s tujimi kolaborativnimi slovarji, predvsem nemškimi, francoskimi in drugimi slovanskimi, že več kot deset let pa se baza zmerno in stalno veča.

Razvezani jezik je oblikovan kot klasičen slovar, v nomenklaturi najdemo gesla, urejena po abecednem redu, ob kliku na geslo pa dostopamo do slovarskega članka. Ker je obrazec za pisanje slovarskih člankov povsem prost (pisec polje izpolni po lastni izbiri), so članki nadvse raznovrstni in nekateri tudi zelo bogati. Tako ponekod najdemo poleg razlage in primera še etimologijo, slovnične in stilske kvalifikatorje, daljše komentarje o rabi ipd. Tudi vsebina je izredno raznolika, članki se nanašajo tako na klasično kot na t. i. popularno kulturo, politično dogajanje, znane osebnosti itn. (Dolar 2014, prim. Dolar in Pangos 2014). Podrobneje se s samo obliko, delovanjem in vsebino slovarja v dani raziskavi ne bomo ukvarjali, pač pa se bomo osredotočili na metafore, ki se pojavljajo $\mathrm{v}$ našem korpusu. Zdi se namreč, da prav kolaborativnost poraja sorazmerno veliko število inovativnih metafor.

\subsection{Znanstvena relevantnost Razvezanegajezika}

Čeprav Razvezani jezik ni reprezentativen korpus, nam veliko pove o aktualnih težnjah jezikovnega razvoja v slovenskem jeziku in je z lingvističnega vidika zelo zanimiv. Gesla in članki pokrivajo vse zvrsti jezika, od knjižnega do pogovornega, in tudi vrsto nestandardnih rab (v slovarju najdemo različne arhaizme, idiome, slengovske in narečne izraze, kletvice, pregovore ipd.). Med njegove glavne prednosti sodi dejstvo, da gre za slovar, ki beleži realne rabe jezika - kako se jezik dejansko uporablja in ne kako naj bi se ga uporabljalo.

Prav tako je izredno ažuren, saj ga sproti posodobljajo govorci - uporabniki

${ }^{1}$ Oktober 2015. 
jezika. Neologizmi se sproti beležijo v spletni leksikalni bazi. Mnogi izrazi se ne obdržijo in ne preidejo v splošno rabo, kar pa samo po sebi ni problematično, saj ne gre za reprezentativen slovar slovenskega jezika. Toda korpus ni dragocen le kot zbirka neologizmov, temveč tudi z vidika lingvistične analize vsebovanih jezikovnih fenomenov. S svojim načinom delovanja se Razvezani jezik umešča v sodobne lingvistične trende, v participativno leksikografijo.

\subsection{Metodologija, zbiranje in obdelava podatkov}

Metafore smo iz korpusa izluščili z ročno obdelavo. Preučujemo jih z vidika njihove slovnične in sintaktične strukture, glede na pomensko polje in semantični transfer, prav tako pa smo se jim posvetili $\mathrm{z}$ vidika njihove inovativnosti in leksikaliziranosti oziroma stalnosti. Tako $\mathrm{v}$ analizi upoštevamo naslednje parametre:

- besedna vrsta metaforične besede oziroma slovnična struktura metaforične besedne zveze,

- semantično polje izhodiščnega pomena (človeško, živalsko, rastlinsko, snovno itn.) oziroma analiza semantične vrednosti ter semantično polje metaforičnega pomena (človeško, živalsko, rastlinsko, snovno itn.) oziroma analiza diskurzivne vrednosti,

- stopnja leksikaliziranosti oziroma konvencionalnosti (konvencionalne, inovativne ali ponovno oživljene, prenovljene metafore).

Podatke o vrednostih kvantitativno primerjamo, najzanimivejše primere obravnavamo kvalitativno. V prvi vrsti pa bomo predstavili, kako smo zamejili predmet raziskovanja.

\section{NEKONVENICONALNE METAFORE?}

Iz korpusa Razvezani jezik, ki vsebuje 4700 gesel, smo ročno izluščili metaforične izraze, ki vsebujejo metafore v geslih oziroma iztočnicah slovarskih 
člankov (kot v primeru hokejist: invalid s palico; pozimi pa na morje hodijo predvsem hokejisti), ne pa tudi metafor v samem besedilu slovarskega članka. Tako v raziskavo nismo vključili metafor, ki se pojavljajo v razlagah (čeprav so sinonimi včasih metaforični, kot denimo žaba v članku diksi: Prenosno stranišče - plastični zabojniki s kemičnim nevtralizatorjem, kijih postavijo ob večjih prireditvah na prostem. Zaradi zelene barve se jim reče tudi žaba.). Prav tako nismo upoštevali metafor, ki se pojavljajo v primerih; v članku ibercuh se metaforična raba denimo pojavi šele $\mathrm{v}$ primeru rabe: prevleka, glazura, končna finišerska obdelava, za pourh, za čisto na koncu; "Za ibercug/h na pet pirov sem pa pred odhodom še en encjan ruknu!".2

Izjema so zbirke, to so članki, kjer so pisci samodejno začeli zbirati različne izraze o določeni temi. Takšnih člankov je v slovarju razmeroma malo (članki kletvice $v$ slovenščini, oguljene fraze, pozdravi, ženske prsi ipd.), pod geslom pa najdemo serijo podiztočnic. Čeprav se podiztočnice ne pojavljajo neposredno v slovarski nomenklaturi, smo jih vseeno vključili v raziskavo, saj so nekatere zanimive $\mathrm{z}$ vidika raziskovanja metafore.

Upoštevali smo gesla, ki eksplicitno navajajo metaforični pomen (kot denimo ovijalka: ženska, ki se $v$ družbi neženirano ovija, slini in pleza po kolegu, izkazujoč svojo neizmerno zaljubljenost; tudi med plesom). Izhodiščni pomen ob metaforičnem ni nujno naveden, saj je ta pogosto očiten. Zdi se torej, da pisci beležijo predvsem manj znane, metaforične in prenesene pomene. Kljub temu nekateri članki navajajo oba pomena, kot denimo članek lipicanec (lipicánec -nca m 1. vrsta konja: jahati lipicanca; dresirati lipicanca; 2. osivel človek, običajno že v pokoju: vsak torek imajo lipicanci posebne popuste; $v$ toplicah

\footnotetext{
2 Pri navajanju primerov smo se odločili za grafično poenotenje (geslo v krepkem, besedilo slovarskega članka $v$ poševnem tisku). Ponekod smo zaradi lažjega razumevanja in berljivosti dodali podpičja (kjer je denimo v članku preskok v novo vrstico brez ločila). Nekatere članke smo zaradi dolžine skrajšali, sicer pa v članke nismo posegali (izjema so le nujni korektorski popravki) niti dodajali. Zajem podatkov: marec-julij 2015.
} 
sem srečala veliko aktivnih lipicancev).

Iz korpusa smo izločili »škrbine«, to so gesla brez razlage oziroma članka. Kadar so škrbine leksikalizirane metafore, kot denimo tavati v temi, dejstvo, da nimajo razlage, ne predstavlja težav za obdelavo. Situacija je drugačna za inovativne metafore, kot denimo pri geslih somalijska kuharica, tomosov nebotičnik, artistka na trapezu ipd., kjer brez informacije o pomenu natančna analiza ni mogoča. Da ne bi prišlo do metodološke nekonsistentnosti, smo torej škrbine v celoti izločili.

\subsection{Različni tipi izrazov s prenesenim pomenom}

Ker Razvezani jezik beleži nestandardne rabe, je prenesenih pomenov v korpusu relativno veliko. Poleg metafor najdemo tudi večje število metonimij in sinekdoh. Metonimija je substitucija na paradigmatski osi, ki po principu stičnosti temelji na logični povezavi (Beth in Marpeau 2005: 26). V primerih biti na igli (drogirati se, zadevati se, biti odvisnik od trdih drog; Tine je "na igli" že dvajset let. (Vir: Delo)) ali žličkar (Arheolog; raba navadno $v$ množini: žličkarji; sopomenka je tudi lopatkar. Ej, če pa žličkarji pridejo, pol si pa u riti, par mescev ne morš niti prdnt, kaj šele zidat.) zamenjava temelji na logičnem dejstvu, da si droge vbrizgavamo z injekcijsko iglo, arheolog pa pri izkopavanju uporablja manjši pripomoček, podoben žlici. Takšna paradigmatska zamenjava je prisotna tudi v naslednjem primeru, ki pojem RTV zamenja z njegovim uličnim naslovom, pri čemer ne moremo spregledati inovativnosti pri pisanju slovarskega članka. 


\title{
Kolodvorska 2-4
}

\begin{abstract}
RTV je v Ljubljani v prostorih Kolodvorska 2 in 4, a je menda nekdanji generalni direktor Janez Čadež hudomušno zahteval, da se namesto Kolodvorska 2 in 4 (ali 2,4$)$ zapiše Kolodvorska 2 do 4 , kar vključuje tudi Kolodvorsko 3 , v kateri je Bangladeš, priljubljeni bife, v katerem lažje najdeś uslužbence RTV-ja kot pa na delovnem mestu na drugi strani ulice.
\end{abstract}

S tem, ko je v naslovu tudi "kakor 3", so dobili alibi, da so na delovnem mestu, tudi tisti, ki so vedrili in oblacili v delovnem času v bifeju.

"Kje pa Janez dela?"

"On je pa dopisnik iz Bangladeša."

Predlagam dopolnilno geslo

Turist (arhaično), bife na mestu sedanje recepcije hotela City, ki je opravljal funkcijo Bangladeša v pionirskih casih RTV. Prizorišce nastopov legend kot so Ježek, Janez Cuk, Mirko Bogataj, Bogdan Plesa

Poleg metonimij v korpusu najdemo tudi druge vrste nedobesednih izrazov, kjer - za razliko od metafore - analogije ni mogoče razbrati. Sem lahko uvrstimo izraze, kot so lešnik (podobno kot kekec izraža nerodnost neke osebe), čebelar (Slabšalni izraz, ki se uporablja za osebo, ki stori nekaj, kar nam ni všeč, ali nam preprosto ni všeč. Res nam je dala največ naloge, ker čebelar stari!), ni pene (Ne skrbi, ni problema. Šel bi na koncert, pa so karte po deset tisoč. Ni pene, poznam nekoga, ki lahko zastonj zrihta.) itn. Zdi se, da tovrstni izrazi nimajo izrazite semantične motivacije.

Prav tako v korpusu najdemo stalne besedne zveze. Ponekod je pomen transparenten in ga lahko enostavno razberemo (pomen besedne zveze je enak seštevku njenih komponent), spet drugje se pomena ne da ugotoviti glede na sestavne dele oziroma motiviranosti v sinhronem vidiku ne moremo razbrati. Takšni primeri so denimo na vrat na nos, norce briti, soliti pamet, biti v elementu ipd. Pomeni teh besednih zvez so preneseni, saj dobesedno nimajo 
smisla. Interpretiramo jih kot semantični blok, ki se ga naučimo kot takega, in $\mathrm{v}$ tem primeru govorimo o frazemih. Pri tem je potrebno opozoriti, da se jim sestavinski pomen lahko začne pripisovati naknadno oziroma da lahko oba pomena sobivata.

Čeprav so preneseni izrazi v korpusu številni in mnogoteri, smo v raziskavi upoštevali le metafore, torej izraze, ki temeljijo na podobnosti oziroma analogiji, ne pa tudi metonimij (temeljijo na logičnih povezavah), sinekdoh (temeljijo na razmerju del - celota) in drugih nedobesednih izrazov in besednih zvez (lešnik, soliti pamet), kjer analogije v sinhronem vidiku ne moremo razbrati. Pri analizi nismo upoštevali t. i. ljudske etimologije (ki se pojavlja denimo v člankih imeti krompir, novinarska raca, oko na 50 kovačev, pijan kot mavra, smeji se kot pečen maček). Toda poudariti je potrebno, da bi kljub jasnim kriterijem lahko še veliko primerov razglasili za mejne (denimo imeti gada v žepu ipd.).

\subsection{Metafora kot morfo-leksikalni postopek}

V sami kategoriji metafor naletimo na dva različna lingvistična fenomena, ki ju je potrebno še posebej izpostaviti: prvič, metafora lahko nastopi kot glavni oziroma edini morfo-leksikalni postopek pri ustvarjanju t. i. semantičnih neologizmov (ko že obstoječa beseda dobi nov pomen, Pruvost in Sablayrolles 2003: 10). Temu bi lahko rekli čista metafora. Mednje sodijo že omenjeni primeri hokejist, ovijalka in lipicanec (prim. zg.).

Nasprotno pa je lahko metafora soudeležena pri tvorjenju besed in se kombinira $\mathrm{z}$ drugimi morfo-sintaktičnimi postopki: rekli bi ji lahko kombinirana metafora. $\mathrm{V}$ tem primeru govorimo o formalnih neologizmih (ko nastane nova beseda, ibid.). Tako lahko zaznamo metaforičnost kot sestavni del leksema oziroma znotraj drugih morfoloških in leksikalnih postopkov. Takšna primera sta benzožer (Avtomobil oz. stroj, ki žre bencin. Fantastična 
zmerljivka. Samo ne nazaj usekati z vprašanjem, koliko stane pri električnem avtomobilu kabel.), kjer metaforična povezava nastane med leksemoma bencin in žreti. Nadaljnji primer je besedna zveza pranje možganov (Vplivanje, manipulacija; Najbolj znana raba v oglaševalskem sloganu, ki se navezuje na temperature pranja $v$ pralnem stroju: "Možgane ti perejo na 9o-6o-9o." -> glede "idealnih" mer za ženske, $v$ skladu s predstavo, da je ženska lepa, če je preščipnjena kot osa (vendar je ta še malo bolj ekstremen pri merah v pasu)), kjer sta metaforično povezana pojma pranje in možgani (slednji pa nastopajo kot metonimija za pamet).

\subsection{Slovnične strukture metafor}

$\mathrm{S}$ formalnega vidika metafore razvrstimo $\mathrm{v}$ dve veliki kategoriji:

- enobesedne metafore oziroma metaforične lekseme,

- metaforične besedne zveze.

Slovnično jedro enobesedne metafore najpogosteje tvorijo samostalnik, pridevnik ali glagol, redkeje pa prislov (Fontanier 1977: 99). V našem korpusu prevladujejo samostalniki (prim. sp.), srečamo tudi glagole, med katerimi je denimo masirati (Poleg dobesednega pomena nosi glagol $v$ preneseni rabi tudi negativno konotacijo. $V$ tem kontekstu pomeni utrujati nekoga $s$ prošnjami, klici, lepimi besedami, blagimi izsiljevanji $v$ zameno za male koristi, usluge ali pozornost. Nehaj me že masirat s temi tvojimi forami! Saj sva se dogovorila, da te pokličem, ko končam z delom.), peteliniti se (postavljati se) ali pa martinčkati se (prim. sp.), katerega osnova je podobnost z vedenjem plazilcev. Slednja sta tvorjena iz primerjalnih frazemov (hoditi kot petelin, greti se kot martinček), kar pomeni, da med enobesednimi in večbesednimi oziroma frazeološkimi izrazi s prenesenim pomenom obstaja tesna povezava. 


\title{
martinčkati se
}

\begin{abstract}
Martinckanje je nastavljanje se soncu, ne nujno le z namenom sončenja, gre predvsem za uživanje prostega časa $v$ brezdelnem posedanju ali poležavanju na prostem ob lepem vremenu. Pojavnost martinckanja v solariju še ni izpričana. Primerna mesta za martinčkanje so plaža (morska, jezerska, obrečna ali visokogorska ob smučišcu, pa tudi kaksen balkon ali klopca in še kaj...). Etimološko sloni na motivaciji

hladnokrvnih plazilcev, ki nabirajo energijo za nove podvige obenem pa premlevajo pretekle dogodke ali enostavno uživajo v strogi sedanjosti, ob cemer se pojem bliža reku carpe diem.
\end{abstract}

Pridevniki so razmeroma redki. Omenimo bio (Interna fora, ki prek asociacij bio = nešpricano, kar ima spet več pomenov, namiguje na spolno privlačnost in udejstvovanje. Vobičajnem jeziku je nešpricano (neškropljeno) sadje bio,je torej zdravo, brez ostankov nevarnih umetnih kemikalij, $v$ danem primeru pa je nešpricano ali 1. brez prïetnega duha, ker ne uporablja parfumov, 2. brez spolnih izkušenj (glagol špricati $v$ pomenu ejakulirati). "Imamo eno kolegico, ki je bio ...") ali počesan (Ta izraz poleg svojega primarnega pomena lahko označuje tudi spremembo $v$ značaju prej srboritega, malo zateženega in nadležnega človeka - ko se malce umiri, sprosti, skulira in je prijaznejši do soljudi, z njimi zbija šale in se neobremenjeno pogovarja, tedaj pravimo, da se počeše. "Odkar se je poročil,je pa počesan. Zdaj še kar pogosto katero rečeva, prej ga pa nisem prenašala ...").

Kot vse stalne in manj stalne besedne zveze se tudi metafore pojavljajo v različnih slovničnih strukturah. Pri metaforičnih besednih zvezah jedro metaforičnosti najpogosteje tvorita glagol ali samostalnik, tako da lahko govorimo o glagolskih ali samostalniških metaforičnih besednih zvezah. Med samostalniškimi najdemo strukture, kot so luč na koncu tunela, brca v temo, hladen tuš, knjižni molj, gradovi v oblakih ipd., med glagolskimi metaforičnimi besednimi zvezami pa denimo biti na robu prepada, biti v slepi ulici, mešati drek ipd. Tako glagolske kot samostalniške metaforične besedne zveze so pogoste in raznovrstne, nasprotno pa je pridevniških 
metaforičnih besednih zvez malo (omenimo za vola ubit ali okolju prijazen: Poleg običajnih primerov uporabe, kjer vsi vemo, za kaj gre, obstajajo tudi bolj zahrbtni ... Primer. Si član glasbene skupine in nekdo ti omeni, kako je tvoj bend okolju prijazen. To ni niti slučajno kompliment. S tem ti hoče povedati, da reciklirate (stare ideje, od starih bendov ... torej ... nič novega ni $v$ vaši glasbi). Če ta oseba konča z manj kot 5 šivi, ste ga premalo udarili.).

$\mathrm{Z}$ vidika strukture ločimo metafore in praesentia ter metafore in absentia in sicer glede na to, ali je primerjani element v metafori prisoten (Človk je prasica) ali odsoten (Vsak torek imajo lipicanci posebne popuste). Metafora in praesentia je zgrajena na eksplicitni primerjavi ter omogoča tudi povezovanje sicer težko združljivih pojmov (Détrie 2001: 61). Pri metafori in absentia pa šele jezikovni in nejezikovni kontekst omogočata interpretacijo, saj deluje kot deixis in predpostavlja določeno pomenskosestavinsko redundanco, da ostane razumljiva (ibid.). Podobno Bacry (1992: 75-80) loči eksplicitno metaforo (ki je zgrajena na kombinaciji oziroma apoziciji metaforične in običajne besede), čisto metaforo (ki je osnovana na zamenjavi običajne besede z metaforično) in indirektno metaforo (kjer je običajna beseda uporabljena $\mathrm{v}$ metaforičnem kontekstu).

\subsection{Analiza pomena in pomenskih polj}

V nadaljnji analizi smo upoštevali semantično (izhodiščni pomen) in diskurzivno vrednost izraza (metaforični pomen). Pri tem smo naredili zelo grobo delitev na pomenska polja, in sicer na človeško, živalsko, rastlinsko in stvarno. Obe pomenski polji (izhodiščni in metaforični pomen) sta lahko identični: že omenjeni hokejist se denimo v obeh pomenih nanaša na človeka, ladja ( $V$ Ljubljani pogosta oznaka za veliko, predvsem daljše in zato manj okretno vozilo; za njegovo upravljanje potrebuješ kar nekaj spretnosti. "Glej ta avto! A ni hud!" "Ja, sam je ladja ..." "Ja, kako bo pa s to ladjo parkiral?!") na stvar oziroma predmet. Zdi se, da je metaforični prenos znotraj istega 
pomenskega polja najpogostejši pri stvareh, morda tudi zaradi dejstva, da je samo pomensko polje izredno široko in bi ga bilo morda smotrno razdeliti še na podskupine.

V zgornjih primerih sta torej pomenski polji enaki. Kadar pa sta različni, lahko določimo smer metafore. Tako lahko glede na njihovo semantično in diskurzivno vrednost govorimo o antropomorfnih, zoomorfnih, fitomorfnih in reifikacijskih metaforah. Antropomorfne metafore uporabljajo za semantično osnovo človeško telo in njegove dele, zoološke uporabljajo živali, njihove lastnosti in dele telesa, fitomorfne rastline in različne dele rastlin (korenine, liste itn.), reifikacijske pa predmete in stvari. V korpusu Razvezani jezik prednjačijo zoomorfne in reifikacijske metafore pred fitomorfnimi in antropomorfnimi. V nadaljevanju bomo predstavili vsako od teh kategorij.

\subsubsection{ANTROPOMORFNE METAFORE}

Pri antropomorfnih metaforah uporabimo človeško telo ali njegove dele, ko govorimo o živalih, rastlinah ali stvareh.3 Mednje sodijo izrazi, kot so esmeralda (Ljubkovalno ime za stavbo Gospodarske zbornice v Ljubljani; dom gospodarstva; ambiciozna zgradba arhitektov Sadar in Vuga je rasla sočasno s priljubljenostjo Esmeralde, žajfnice o "pepelki s konca drugega tisočletja". Esmeralda je imela zelene oči in se oblačila $v$ zeleno, zbornica pa zelene šipe in zelene okvirje.), rudar (nekdanji bankovec za 1000 dinarjev; rjav; "To te bo koštalo pol rudarja (=50o dinarjev)), tarzančki (brabonci, abranki; ostanki posušenih drekcev, ki visijo na dlakah okoli anusa ali spolovila). Pri teh izrazih je osnovno pomensko polje človeško, izrazi pa prek personifikacije preidejo v stvarno, zato govorimo o antropomorfnih metaforah.

\footnotetext{
3 Nasprotno Snoj (2010: 101) primere, kot so »lisjak « (prebrisan moški) klasificira kot antropomorfne. Metaforična pomenska »izpeljava se tipsko opredeljuje kot antropomorfna: poimenovanja, ki pomensko niso povezana s človekom, se preko asociativne (metaforične) povezanosti vsebin uporabljajo tako, da ustrezajo potrebi po imenovanju lastnosti, ki se naključno prisoja $\mathrm{v}$ osebku imenovani osebi (oseba kot nosilec specifičnih človeških lastnosti)« (ibid.).
} 
Zdi se, da je tovrstnih izrazov v Razvezanem jeziku sorazmerno malo.

\subsubsection{ZOOMORFNE METAFORE}

Nasprotno bi lahko rekli, da so zoomorfne metafore zelo pogoste; ta metaforični proces pripisuje živalske lastnosti človeku, lahko pa tudi rastlini ali predmetu. Metafore lahko izhajajo iz poimenovanja za celotno žival, iz poimenovanja za del njenega telesa (in njegovih formalnih ali funkcionalnih značilnosti) ali pa značajskih lastnosti, ki jih pripisujemo živalim.4

Primeri v Razvezanem jeziku so zares številni, med njimi najdemo predvsem prehod iz živalskega $\mathrm{v}$ človeško pomensko polje. Večina živalskih metafor se nanaša na karakterne lastnosti oziroma vedenje, ki ga pripisujemo živalim. Med njimi najdemo serijo kačjih metafor: boa, gad, modras, naočarka, mamba, udav (so nevarne in strupene) ter živali, kot so voluhar (gnjavi; živi od rezultatov tujega dela), zlata ribica (velikokrat pozablja), žaba (se napihuje), čuk (štorast), hrček (vse pridno hrani), knjižni molj, morska zvezda (Oseba, ki med spolnim odnosom zgolj pasivno leži z vsemi štirimi narazen, ne da bi karkoli sodelovala ali sploh reagirala. "Ste morda kaj spolno aktivni?" "Ne, jaz samo ležim tam."), peteliniti se (prim. zg.), veverica na drevesu (nedosegljiva ženska) ali pa galeb (Politik, ki vrešči, veliko požre, povsod naokrog serje in leta (menjuje) od politične stranke do stranke. Slednje je tudi značilnost obmorskih fantov-galebov, ki vsako noč zadovoljijo drugo turistko; po F. M. Ježku je bil Galeb najpožrešnejša ptica. Mislil je Titovo ladjo Galeb.). Prav tako imamo tudi splošnejše oznake oziroma oznake za določeno kategorijo (denimo sivi panterji in lipicanec za upokojence). Živalske metafore lahko izražajo dejanja, denimo daviti purana (moško samozadovoljevanje (spolni ud = tič = "puran", daviti, ker ga držiš s celo dlanjo)), gada naviti (nasrati drek v krogu; narediti dolgo zavito klobaso), petelinji zajtrk (jutranji seks, seks navsezgodaj, seks ko se zbudiš, seks za

4 Podrobno se je z živalskimi metaforami in frazemi pri nas ukvarjal Keber $(1996,1998)$. 
dobro jutro). Med metaforami za človeško telo in njegove dele prednjačijo oznake za moške spolne organe (enooki kačon, pes čuvaj, piton ipd.).

Prav tako se zoomorfna metafora pojavlja pri prehodu iz živalskega v stvarno, denimo krokodilčki (ščipalke za obešanje perila), školjkica (poseben način lepljenja z lepilnim trakom: lepilni trak upognemo $v$ kolobarček, tako da ga prilimamo samega nase in ga nato pritrdimo na papir z zadnje strani), prestave na metuljčka, rdeči petelin ali dinozavrova jajca (prim. sp.).

\section{dinozavrova jajca}

v belo plastiko ovite bale sena

Novejši pojav na domačih travnikih (od sredine 9o-ih let dalje). Bale sena, ovite $\mathrm{z}$ raznobarvno silažno plastiko, izpodrivajo klasicno spravljanje sena (s tem pa tudi puhalnike in kozolce) ter pomembno prispevajo k novim vedutam slovenske krajine. Bale nastopajo sicer v več barvah, bele pa zaradi okrogle oblike in velikosti spominjajo na dinozavrova jajca.

Šušlja se, da si je izraz izmislil snemalec nacionalne televizije, saj mu bale (pre)veckrat polvarijo sicer lep kader s pristno slovensko pokrajino.

Zanimivo je dejstvo, da se metafore $\mathrm{v}$ korpusu pogosto navezujejo na arhitektonske objekte (kanarček za Dnevnikovo zgradbo, črna vdova za Delovo stolpnico, močerad, prim. sp.).

\section{močerad}

Vzdevek za kričečo arhitekturo iz rumenih in črnih keramičnih ploščic v Trnovskem pristanu v Ljubljani, ki jo je arhitekturni duo Sadar Vuga učeno poimenoval Kondominij.

\section{$>\underline{\text { Kdo živi v močeradu? }}$}

Med zoomorfnimi metaforami najdemo tako enobesedne metafore (galeb, 
hrček, krokodilčki, boa, vrečar itn.), kot tudi metaforične besedne zveze (ubogi pes, veverica na drevesu, črna vdova, kobila na pleh ščije, mačka po špeh poslat ipd.), ki po številu rahlo prednjačijo. Zanimive so variante, kot sta pljuž ali bak, ki sta narečni različici polža in bika.

\subsubsection{FITOMORFNE METAFORE}

Fitomorfne metafore se naslanjajo na analogijo med rastlinami (ali njihovimi deli ipd.) ter drugimi kategorijami (ljudmi, živalmi, predmeti). Fitomorfne metafore so v korpusu številčno manj prisotne, so pa zato nadvse raznolike. Nanašajo se lahko na del telesa, kot denimo kisla repa (viseči, ravni, tudi mastni lasje, ki jih je težko oblikovati $v$ spodobno pričesko), banana (penis), mokrocveteča rož'ca (zamakajoča vagina), na vedenje ali karakterno lastnost: ovijalka (prim. zg.), fikus (prim. sp.), goba (označuje žensko, ki je sposobna popiti velike količine alkohola, ne da bi le-te vplivale na njene mentalne sposobnosti, je torej ne upijanijo), kostanjček (Otrok, ki je pred kratkim shodil. Glava je v razmerju do telesa prevelika, roke štrlijo navzven ali naprej. Otrok se pri hoji opoteka ter na silo zaustavlja. Lahko tudi večkrat pade.), pognati korenine itn.

\section{fikus}

\section{Označuje osebo, od katere je toliko življenja in koristi, kot od vsakega fikusa v pisarni. Torej malo nič... Običajno dobite takšen občutek pri komuniciranju z zaposlenimi v javni upravi. Vsem prizadetim, ki ne spadajo v ta okvir, se opravičujem.}

\section{"Sem klicala na davčno, ampak je bil na drugi strani samo en fikus in nisem uspela izvedeti nič pametnega." \\ "Tajnica našega ravnatelja niti papirja ne premakne. Zgolj za fikus jo imamo."}

Fitomorfno poimenovanje bonsai se humorno nanaša na Milana Kučana, sicer pa lahko prehod poteka tudi od rastlinskega $\mathrm{k}$ stvarnemu (ikebana: 
največkrat lesena površina (vrata, drog,...), ki se običajno nahaja $v$ zapuščenih stavbah, $v$ katerih junxi zabijajo igle, štajerska solatka: Štajerska solatka je $v$ bistvu kozarec vina ob kosilu. Primer: A bi zraven piščanca tudi malo štajerske solatke?, regrat: vzdevek za Spomenik revolucije na Trgu republike $v$ Ljubljani). Prevladujejo metaforični leksemi (fikus, banana, lubenica, ovijalka, goba ipd.), najdemo pa tudi metaforične besedne zveze (pognati korenine, kisla repa, mokrocveteča rož'ca, štajerska solatka ipd.). Omenimo kreativno metaforo pogobniti - glagol izpeljan iz samostalnika goba - pomeni stopiti v vodo s čevljem in pri tem zajeti vodo vanj. Na širšem območju do Trojan pomeni tudi pogrezniti se v vodo ali blato.

\subsubsection{REIFIKACIJSKE METAFORE}

Reifikacijske metafore temeljijo na zamenjavi živega bitja (najpogosteje človeka, lahko pa tudi živali ali rastline) s predmetom. Takšne so metafore tipa obešalnik: Šaljivo, čeprav lahko tudi z zaskrbljenim prizvokom, poimenovanje za zelo suhega ali vsaj po mnenju govorca presuhega človeka. Obešalnik zato, ker naj bi suhcu obleke kar visele, kot na obešalniku. "Kakšen obešalnik si, ubogi revež, kaj ti doma ne dajo nič za jest? "

Kategorija reifikacijskih - podobno kot zoomorfnih - metafor je zelo velika, a verjetno tudi zato, ker »stvarno « pokriva izredno široko pomensko polje, tako da v njem denimo najdemo pojme, ki so povezani z avtomobilizmom, prehrano, inštrumenti itn. Prehod poteka skoraj izključno od stvarnega k človeškemu, kot v naslednjem primeru: 


\section{bojler}

\section{Nevošcljivo poimenovanje trebušnega predela pri moškem, ko vsled "pretiranega pretiranega treniranja nekaterih mišic" t.i. "sixpack" "prerase v eno samo, ampak zato toliko močnejšo in bolj opazno "mišico"'". Moški z bojlerjem so podvrženi napadom bauč'ka.}

\section{Primer: Ima pa bojler kot bi bil v devetem mesecu (nosečnosti)!}

Reifikacijske metafore se nanašajo bodisi na del človeškega telesa (kepa na glavo, picerija na mozoljast obraz, radiatorčki, mišelinke in bojler (prim. zg.) na trebuh, podboj in vogal od banke na boke in zadnjico, airbagi, čajne vrečke, sifoni in odbijači na ženske prsi, cabrio in žvarovna na penis) bodisi na značajsko oziroma vedenjsko lastnost (driska na tečnega človeka, kanta za smeti na starša, ki poje ostanke otrokovega obroka, copata na podrejenega moškega, huskvarna na jezikavo žensko, prikolica na spremljevalko, ženo, punco, trobente na pijane ljudi itn.), redkeje pa na človeka v celoti oziroma na določeno kategorijo (fosil: 1. penzionist; 2. zastarelo razmišljujoč človek; 3. pristaš milozvočne popevkarske scene).

V kategoriji reifikacijskih metafor najdemo tudi lekseme tujega izvora (ang. airbagi, it. cabrio in lampadinar) in lastna imena (mišelinke, nestle, huskvarna), ki služijo kot podstava za nadaljnje jezikovne kreacije. Prevladujejo metaforični leksemi, metaforične besedne zveze so redkejše.

\subsection{Inovativne in leksikalizirane metafore}

Metafore lahko preučujemo tudi glede na njihovo stopnjo stalnosti oziroma leksikaliziranosti, kjer razlikujemo med inovativnimi in leksikaliziranimi metaforami, torej metaforami, ki vzpostavljajo neko novo analogijo in zahtevajo lastno interpretacijo, ter metaforami, ki so prešle v splošno rabo in jih govorci interpretirajo kot semantični blok. 
Ricœur prve imenuje žive metafore: gre za inventivne metafore, ki ustvarjajo nove metaforične povezave in pomene. Imajo status dogodka, saj se pojavljajo le v danem kontekstu in zahtevajo celoten interpretativni proces. Pogosto je možnih več povsem različnih interpretacij oziroma je metafora ambivalentna, pomen pa se konstituira glede na jezikovni in nejezikovni kontekst in ni dan vnaprej. Gre za diskurzivno dejanje oziroma za diskurzivni fenomen, za nekakšno neposredno kreacijo ali semantično inovacijo, ki vsebuje novo informacijo in pove nekaj novega o realnosti (Ricœur v Foessel in Lamouche 2007: 118-119). Med inovativne metafore lahko štejemo besedne zveze, kot so drek v ventilatorju (Okoliščine, ki si jih nikakor ne želimo. Ko je nekaj slabo oziroma pokvarjeno in je potrebno veliko znanja, truda in časa za vzpostavit normalno stanje. Tako kot očistiti drek, ki ga je na vse strani raznesel ventilator. Na primer: Ključ od avta sem zaklenil, nimam rezervnega, pa imam drek $v$ ventilatorju.), delati iz pičke kapelco (nenehno, venomer in neutrudno komplicirati enostavne stvari), a vzameš goloba v benetke (Tako vprašamo, kadar nas kdo vpraša, ali gremo kam s svojo boljšo polovico. Recimo: "O, greš na morje?" "Ja, jutri." "Kaj pa žena?" "Ja, a vzameš goloba $v$ Benetke?" Torej: zakaj bi s seboj vzel ženo, ko pa bo na morju dovolj druge paše za oči.), dvostranski tisk (Ko si zaradi maksimalne ekonomičnosti obrišeš rit z obema stranema toaletnega papirja.) ipd. Pri teh metaforah je interpretacija močno odvisna od konteksta in lahko njen pomen variira. 5 Občasno tudi znotraj istega članka najdemo več metaforičnih pomenov, kot denimo pri izrazu bio (prim. zg.).

Nasprotno pa mrtve (Ricœur v Foessel in Lamouche 2007: 118-119) oziroma leksikalizirane metafore govorec interpretira kot nemotiviran semantični blok. Za Snoj se leksikaliziranost »v širšem smislu nanaša na dejstvo, da se asociacija, ki povezuje dvoje vsebin, lahko odraža v dveh metaforično povezanih pomenih

5 Pri tem je potrebno opozoriti, da sam vnos v Razvezani jezik načeloma predpostavlja, da neko mikrookolje (čeprav je to lahko le nekaj govorcev) izraz razume v smislu semantičnega bloka. 
ali metaforičnih rabah danega pomena«, leksikalizirana metafora pa »se nanaša na specifičnost metaforičnega pomenskega prenosa s stališča ustrezanja zahtevam glede strukturiranosti slovarskega pomena « (Snoj 2010: 26 in 68). Mrtve metafore so del konvencije jezikovne skupnosti. Takšni primeri so denimo besedne zveze knjižni molj, jebati ježa, gradovi v oblakih, hladen tuš, ki so z vidika interpretacije mnogo enostavnejši, saj kontekst ne igra tako velike vloge. Zdi pa se, so besedne igre, ki v ospredje postavljajo ne metaforični pomen mrtvih metafor, sorazmerno pogoste. Prav soobstoj obeh pomenov, sestavinskega in prenesenega, je vir številnih jezikovnih iger (Mejri 2005: 193).

Seveda gre za dva ekstrema, ki se nahajata na nasprotnih polih lestvice metaforičnosti: leksikaliziranost je namreč kontinuum, tako da lahko govorimo predvsem o stopnjah (Détrie 2001: 206-221). Prav tako so lahko mrtve metafore »oživljene« oziroma "pomlajene« in tako omogočajo novo konceptualno produkcijo (Ricœur 1975: 370-375). Gre za pojav, ki je v frazeologiji znan kot prenovitve (Kržišnik 1987) oziroma obnovitve (Korošec 1998: 124-129). Bordas opozarja, da je lahko vsaka metafora »oživljena«, če se eden od njenih pomenov »reaktivira«. Ti primeri so v Razvezanem jeziku sorazmerno redki in bi morda mednje lahko pogojno šteli naslednji izraz:

\section{podželviti}

\section{izgubiti proti šibkejšemu/počasnejšemu nasprotniku;Izraz izhaja iz Ezopove basni o zelvi in zajcu, ki je poražen v teku zaradi podcenjevanja nasprotnika.}

V bolj filozofskih krogih se izraz nanaša na Zenonov paradox 0 Ahilu in želvi, kjer hitrejši zasledovalec počasnejše želve nikoli ne dohiti. $\mathrm{V}$ tem primeru podželviti pomeni zabresti v nalogi, ki je že vizhodišcu izgubljena.

Glagol izhaja iz metafore želva (nekaj počasnega, neokretnega), aktivira pa 
pomena podcenjevanje in zabrestiv nalogi, ki v prvotnem metaforičnem izrazu nista nujno prisotna. Za nadaljnjo analizo bi potrebovali zgled rabe, a ga Razvezani jezik žal ne ponuja. Metafore imajo tako aktiven potencial, ki se ga lahko prikliče $\mathrm{v}$ določenih kontekstih izjavljanja, kadar se ti oddaljijo od običajnega. Ta potencial izhaja iz ambivalentnosti same strukture metafore (Bordas 2003: 27), pri čemer je potrebno opozoriti, da proces deleksikalizacije ni simetričen procesu leksikalizacije (Ricœur 1975: 370-375).

\section{ZAKLJUČEK: RAZVEZANE METAFORE}

V raziskavi smo preučevali različne vrste metafor. $V$ prvem delu razprave smo predstavili teorije metafore $\mathrm{v}$ različnih lingvističnih in tudi širših teoretskih okvirih (retorika, strukturalna lingvistika, pragmatične, kognitivne in besedilne analize). Nemara med temi pripade posebno mesto strukturalni lingvistiki, kjer je Jakobson metafori pripisal eno od dveh osnovnih razsežnosti jezika, in jezikovni pragmatiki, kjer je kontekst, ki lahko vsebuje jezikovne in nejezikovne elemente, ključnega pomena za konstituiranje in interpretacijo metafore. Metaforo smo za potrebe razprave definirali kot lingvistično operacijo, ki na podlagi implicitne primerjave vrši zamenjavo na paradigmatski osi, pri čemer pride do zbližanja in trka različnih pomenskih polj.

V nadaljevanju smo predstavili nekonvencionalni korpus Razvezani jezik, ki je kolaborativni slovar slovenskega jezika. To je spletna leksikalna baza, v kateri pisci prispevajo nova gesla in članke, obenem pa lahko spreminjajo in dopolnjujejo že obstoječe. Čeprav korpus ni reprezentativen in tudi ne izčrpen, pa je zelo zanimiv $\mathrm{z}$ vidika raznovrstnih lingvističnih inovacij: vsebuje sorazmerno veliko semantičnih in formalnih neologizmov, ki nam omogočajo vpogled v morfo-leksikalne mehanizme jezikovne inovativnosti. To velja tudi za metafore in druge oblike prenesenih rab, kot so metonimije, sinekdohe, frazemi ipd. 
Z jezikovnega vidika lahko ločimo čiste in kombinirane metafore in sicer glede na to, ali se metafora kombinira z drugimi morfo-leksikalnimi postopki ali pa se pojavlja sama. Izpostavili smo različne slovnične lastnosti metafor, ki smo jih razdelili na enobesedne metafore in metaforične besedne zveze. Prav tako smo omenili različne sintaktične funkcije metaforičnih izrazov (predikativna, atributivna, apozitivna ipd.). Pomembna je tudi strukturna delitev na metafore in praesentia ter in absentia.

Analiza pomenskih polj je pokazala, da je največ metafor v Razvezanem jeziku zoomorfnih. Te najpogosteje slonijo na analogiji med živalskim in človeškim ali pa živalskim in stvarnim (kjer najdemo denimo živalska poimenovanja za arhitektonske objekte). Večina živalskih metafor se nanaša na karakterne lastnosti oziroma vedenje ljudi, najdemo pa tudi splošnejše oznake, živalske metafore za dele človeškega telesa, dejanja ipd. Med reifikacijskimi metaforami, ki slonijo na metaforični zamenjavi živega bitja s predmetom, poteka metaforični proces skoraj izključno od stvarnega k človeškemu (tudi tu so najpogostejše metaforične oznake za značajske lastnosti ali dele telesa). Ta kategorija je sicer velika in mnogotera, saj pokriva zelo široko pomensko polje, najdemo pa tudi lekseme tujega izvora in metaforične jezikovne kreacije na osnovi lastnih imen, kjer lastno ime služi kot podstava za nadaljnje lingvistične postopke. Fitomorfne metafore, ki se naslanjajo na analogijo med rastlinami in njihovimi deli in drugimi pomenskimi polji, so številčno manj prisotne, vendar raznovrstne, medtem ko so antropomorfne metafore v korpusu redke. Glede na obravnavane primere se torej zdi, da pogosto uporabljamo živalsko in stvarno pomensko polje, kadar govorimo o človeški, nasprotno pa človeške ne za ostale kategorije.

Pri obravnavi metafore je pomembna opozicija med invativnimi in leksikaliziranimi metaforami: invativne ali žive metafore vzpostavljajo neko novo analogijo, metaforično povezavo in pomen. So močno odvisne od konteksta in zahtevajo celoten interpretativen proces. Leksikalizirane, mrtve 
metafore so del lingvističnega koda in jih interpretiramo kot semantični blok. Poudariti je potrebno, da gre pravzaprav za dva pola, večina metafor pa se nahaja na lestvici med njima. Čeprav se žive metafore prav kot take izmikajo vsakršnemu uslovarjenju, pa se zdi, da je Razvezani jezik morda pravšnje mesto za beleženje takšnih rab in priča o možnostih, inovativnosti in kreativnosti v slovenskem jeziku.

\section{LITERATURA}

Amalric, J.-L. (2006): Ricœur, Derrida. L'enjeu de la métaphore. Pariz: PUF. Aristoteles (1982): Poetika. Ljubljana: Cankarjeva založba.

Bacry, P. (1992): Les figures de style. Pariz: Belin.

Beth, A., in E. Marpeau (2005): Figures de style. Pariz: Librio.

Bordas, E. (2003): Les chemins de la métaphore. Pariz: PUF.

Bratož, S. (2010): Metafore našega časa. Koper: Fakulteta za management.

Čeh Steger, J. (2001): Metaforika v Cankarjevi kratki pripovedni prozi. Maribor: Slavistično društvo.

Derrida, J. (1972): Marges de la philosophie. Pariz: Minuit.

Détrie, C. (2001): Du sens dans le processus métaphorique. Pariz: Honoré Champion.

Dolar, K., in I. Pangos, ur. (2014): Razvezani jezik XXXY. Ljubljana: Društvo za domače raziskave.

Dolar, K. (2014): Kolaborativni slovar Razvezani jezik. Slavistična revija, 62 (2): $235-252$.

Ducrot, O. (1984): Le dire et le dit. Pariz: Minuit.

Dumarsais, C. Ch. (1977): Traité des tropes. Pariz: Le Nouveau commerce.

Fontanier, P. (1977): Les figures du discours. Pariz: Flammarion. 
Greimas, A. J. (1966): Sémantique structurale. Pariz: Larousse.

Grice, H. P. (1989): Studies in the Way of Words. Cambridge (Massachusetts): Harvard University Press.

Fauconnier, G., in M. Turner (1998): Conceptual Integration Networks. Cognitive Science, 22 (2): 133-187.

Foessel, M., in F. Lamouche (2007): Ricœur. Pariz: Points.

Jakobson, R. (1989): Lingvistični in drugi spisi. Ljubljana: ISH.

Kante, B. (1996): Metafora in kontekst. Ljubljana: Jutro.

Kante, B., ur. (1998): Kaj je metafora? Ljubljana: Krtina.

Keber, J. (1996): Živali v prispodobah 1. Celje: Mohorjeva družba.

Keber, J. (1998): Živali v prispodobah 2. Celje: Mohorjeva družba.

Kleiber, G. (1999): De la sémantique de la métaphore à la pragmatique de la métaphore. V N. Charbonnel in G. Kleiber (ur.): La métaphore entre philosophie et rhétorique: 3-13. Pariz: PUF.

Kleiber, G. (1990): La sémantique du prototype. Pariz: PUF.

Korošec, T. (1998): Stilistika slovenskega poročevalstva. Ljubljana: Kmečki glas.

Kržišnik, E. (1987): Prenovitve stalnih besednih zvez v Kosmačevi prozi 30. let. V F. Zadravec (ur.): Socialni realizem $v$ slovenskem jeziku, književnosti in kulturi: 517-532. Ljubljana: Filozofska fakulteta.

Kržišnik, E. (1994): Slovenski glagolski frazemi (doktorska disertacija). Filozofska fakulteta, Univerza v Ljubljani.

Lakoff, G., in M. Johnson (1992): Metaphors We Live by. Chicago in London: The University of Chicago Press.

Lakoff, G. (2002): The Contemporary Theory of Metaphor. V A. Orthony (ur.): 
Metaphor and Thought: 202-251. Cambridge: Cambridge University Press.

Lala, M.-Ch. (2005): La métaphore et le linguiste. Figures de la psychanalyse, 11 (1): 145-161.

Mejri, S. (2005): Figement absolu ou relatif: la notion de degré de figement. Linx, 53: 183-196.

Močnik, R. (1988): A Theroy of Metaphor. V T. Mastnak in R. Riha (ur.): The Subject in Democracy: 86-93. Ljubljana: ZRC SAZU.

Novak-Popov, I. (1997): Prispevek k analizi metafore v sonetu postmodernizma. Jezik in slovstvo, 42 (6): 215-228.

Orthony, A., ur. (2002): Metaphor and Thought. Cambridge: Cambridge University Press.

Pangos, I., in A. Pirman, ur. (2007): Razvezani jezik. Ljubljana: Društvo za domače raziskave.

Pogorelec, B. (1986): Okvirna tipologija metafore v slovenski prozi 20. stoletja. V 22. seminar slovenskega jezika, literature in kulture, Zbornik predavanj: 7-20. Ljubljana: Filozofska fakulteta.

Pruvost, J., in J.-F. Sablayrolles (2003). Les néologismes. Que sais-je? Pariz: PUF.

Rastier, F. (1987): La sémantique interprétative. Pariz: PUF.

Razvezani jezik. Dostopno prek: http://www.razvezanijezik.org/ (marec 2015).

Ricœur, P. (1975): La métaphore vive. Pariz: Seuil.

Searle, J. R. (2002): Metaphor. V A. Orthony (ur.): Metaphor and Thought: 83-111. Cambridge: Cambridge University Press.

Slovenski etimološki slovar (1997). M. Snoj (ur.). Ljubljana: Mladinska knjiga. 
Snoj, J. (2010): Metafora v leksikalnem sistemu. Ljubljana: ZRC SAZU.

Sperber, D., in D. Wilson (1989): La Pertinence. Communication et cognition. Pariz: Minuit.

Stramljič Breznik, I. (2004): Metafora v slovenskem besedotvornem izrazju. V M. Humar (ur.): Terminologija $v$ času globalizacije: zbornik prispevkov s simpozija Terminologija $v$ času globalizacije, Ljubljana, 5.-6. junij 2003: 93-101. Ljubljana: ZRC SAZU.

Vidovič-Muha, A. (2000): Slovensko leksikalno pomenoslovje: govorica slovarja. Ljubljana: Znanstveni inštitut filozofske fakultete. 


\section{INNOVATIVE AND LEXICALIZED METAPHORS IN SLOVENE}

The metaphor is a multidisciplinary problem which has been addressed in linguistics as well as in philosophy, psychology, anthropology, etc. In linguistics, the problem of metaphor was dealt with in rhetorics, it occupied a special place in structural linguistics, and it was studied in diverse pragmatic, cognitive and textual analysis. In the present paper, metaphors in Slovene are analyzed from the linguistic point of view: grammatical and syntactic structure (monolexical/polylexical, in praesentia/in absentia, etc.), semantic field and semantic transfer and degree of conventionality (ranging from innovative to lexicalized metaphors). The cases are taken from the unconventional linguistic corpus, Razvezani jezik, an online dictionary based on collaborative authorship. Authors can freely add new words (formal neologisms) or new meanings of existing ones (semantic neologisms) which makes it especially interesting for linguistic innovation research. The results show that zoomorphic metaphors are most common and that there is a significant number of reification metaphors (replacing a living being with an object). Phytomorphic metaphors (related to plants) are also present, whereas anthropomorphic ones are scarce. These types of metaphors most often refer to character, personality or human behavior, but also to parts of human body, human actions, etc. The corpus is rich in both, lexicalized, conventional as well as in innovative, so called live metaphors, and it seems that Razvezani jezik, an online database for Slovene, is particularly suitable to register these diverse possibilities and usages.

Keywords: creative metaphors, lexicalized metaphors, linguistic innovation, collaborative dictionary, history of metaphor 
To delo je ponujeno pod licenco Creative Commons: Priznanje avtorstvaDeljenje pod enakimi pogoji 2.5 Slovenija.

This work is licensed under the Creative Commons Attribution ShareAlike 2.5 License Slovenia.

http://creativecommons.org/licenses/by-sa/2.5/si/

(C) (1) () 